\title{
The Management Of Research And Development And The Relevance Of Financial Accounting
}

Paul E. Nix, Montana State University - Bozeman, E-mail: pnix@montana.edu Roberto de Magalhaes, Texas A\&M University, E-mail: roberto@cob.tamucc.edu William Wilcox, Bradley University -- Illinois, E-mail: wwilcox@bradley.edu

\begin{abstract}
This study investigates alternatives to current financial accounting treatment of research and development expenditures in United States public corporations. A questionnaire survey was sent to members of the Financial Directors Network of the Industrial Research Institute of America, representing over forty percent of private research and development in the United States. Background research and the survey indicate that if the financial reporting of research and development is modified, research and development will increase and a shift from short-term to long-term projects will occur; and finally United States public corporations will more effectively compete in the international markets.
\end{abstract}

\section{Synopsis and Introduction}

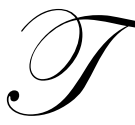

he outlook for R\&D in 2001 continues to be strong. In 1998, U.S. R\&D grew by $6.5 \%$ after adjusting for inflation. However, "Of the top 20 corporations investing in $1998 \mathrm{R} \& \mathrm{D}$, only eight will be U.S. firms. It was not long ago that U.S. firms dominated the top 20 list with 15 of the largest of the R\&D spenders" (Wolff, 2000). The Council on Competitiveness report states "...the United States is not laying the foundation for its long-term prosperity...based upon R\&D statistics" (Council on Competitiveness, 1999). "The trend away from basic research toward more product development and technical service, first detected in the late 1980's...continues" (Wolff, 1994). Numerous studies with controversial results have investigated the possible effects of the financial accounting treatment of U.S. R\&D expenditures on R\&D spending (Dukes, 1980; Elliott, 1984; Ball, 1980; Bierman and Dukes, 1975; Braitwaite, 1967). The forces that influence R\&D spending in addition to financial accounting are many and varied including management, internal cash flow, capital markets, government policy and perhaps most important available research projects. Financial accounting may be becoming less relevant to external users and the capitalization of R\&D may be useful (Lev and Zarowin, 1999). In an information based economy, R\&D should be even more important; however, research discloses in a random sample of the Fortune 500 companies that R\&D as a percent of sales has remained constant from 1986 through 1998 (Compustat Data, 1999). Why has R\&D not increased in importance to sales? The effect of the financial accounting of R\&D expenditures on R\&D spending may be part of the answer.

Historically, expensing versus capitalizing research and development (R\&D) expenditures has long been an important and controversial topic with few popular accounting treatments (Lev and Zarowin, 1999; Nix, 1992; Gellein and Newman, 1973; Wolf, 1989; Marshal, 1980; Newman, 1988; Munson, 1987; Nixon and Lonie,

Readers with comments or questions are encouraged to contact the authors via email.

1990; Guerard, 1987; Selto and Clouse, 1986; Horwitz and Kolodny, 1980; Wolfson, 1980; Higgins, 1954). The mandated accounting treatment, SFAS No. 2, 1974, which requires public corporations to expense R\&D expendi- 
tures in the period incurred, provides a strong incentive to decrease $R \& D$, because expensed R\&D has an immediate adverse impact on reported profits. International business firms do not suffer under this impact which may effect the relevancy of financial earnings (Barth and Clinch, 1998; Carnegie and Turner, 1987). Imagine expensing a plant during construction, such as the multi-million dollar Utah chip production plant which never opened in 1999 or 2000. The same effect may occur when intangible assets arising from research costs are expensed in the year they are incurred. The mandated expense treatment provides an incentive to spend a disproportionate share of R\&D on projects that have a short-term rather than long-term return. Researching a new product frequently requires a 5 to 10 year investment (Biggadike, 1979). Traditionally the product life cycle has been even longer. Thus research planning influenced by quarterly or annual reported earnings may adversely affect both individual companies as well as our national economy. When a capital asset such as $R \& D$ is expensed in the year incurred, reported income is distorted due to a lack of matching of expenditures with related revenue generation (Thomas, 1969). Prior to 1974, financial reporting of R\&D expenditures ran the gauntlet between full capitalization in the year incurred versus full expensing in the year incurred (SFAS No. 2, 1974). The impact of tax policy on financial reporting no doubt influenced the passage and acceptance of SFAS No. 2. The use of a contra stockholders' equity account in which all $\mathrm{R} \& \mathrm{D}$ expenditures would be placed when incurred and then later amortized is a possible compromise solution; immediate write off for tax purposes need not be affected (Raby, 1967; Tax Foundation, 1990). At the end of each year a fixed percent (such as 20\%) of what is remaining in the equity account from prior years' expenditures would be charged to R\&D expense for the current year. With this proposed contra stockholder account method, during periods of increasing $R \& D$ expenditures, current $R \& D$ expenses would be less than under the required expense-asincurred method. Thus, under the proposal, the current R\&D expenditures would be expensed over their future revenue-producing period; but, during periods of decreasing $R \& D$ expenditures, current $R \& D$ expenses would be greater under the proposed method than in current practice. Again, R\&D expenditures are more closely matched to their revenue-producing period. When there is no change in the total $\mathrm{R} \& \mathrm{D}$ expenditures from year to year, current $R \& D$ expenses would be the same under the proposal and the required expense-as-incurred method. Thus, $R \& D$ expenditures would be more closely matched to $R \& D$ revenue generated under the proposed contra stockholder equity account method under all budgeting situations. The proposal also encourages a shift from short- to long-term R\&D under all three situations. (See Illustration of "Contra Stockholder Equity" Approach)

The use of a contra stockholders' equity approach is already required and used in accounting for the unrealized loss on long-term marketable securities, the translation gains and losses on foreign currency amounts, the net loss not recognized as pension expense and treasury stock transactions (SFAS No. 12, 1975; SFAS No. 52, 1981; SFAS No. 87, 1988).

In the current study members from the Financial Directors Network of the Industrial Research Institute, representing over 40 percent of the industrial R\&D in the U.S., responded to a questionnaire survey. Greater than $50 \%$ of those receiving the questionnaire replied in a usable format. These respondents represent corporations, which account for over 20 percent of the corporate R\&D spending in the U.S. The average annual R\&D expenditures of these companies are $65 \%$ of average annual profits. When R\&D expenditures are $65 \%$ of profits, it is easy to picture how, under current practice, $R \& D$ expenditures may be cut back to boost profit during a profit squeeze.

\section{Results of Questionnaire}

Questions asked referred to the use of such a contra stockholders' equity account and to what was the most appropriate financial disclosure of $\mathrm{R} \& \mathrm{D}$ expenditures in general. When asked the following question, "After enactment of this proposal, the current year's expenses would normally be unaffected by the current year's $R \& D$ expenditures. When current profits are unsatisfactory to higher management, in general, what effect (if any) would the proposed method have on current year $R \& D$ expenditures relative to the now required expense as incurred practice?" $48 \%$ indicated that they would increase their current year's R\&D, $12 \%$ indicated a decrease, and $40 \%$ indicated no change. These results indicate that our present "expense as incurred rule" may well inhibit total R\&D expenditures in the periods they are most badly needed. Also, some companies would be affected while many others would not.

\section{Illustration of "Contra Stockholder Equity" Approach}


short-term R\&D expenditures under the proposed method, while $56 \%$ indicated there would be no effect. United States industry has, for many years, been frequently criticized for emphasizing short-term returns at the expense of overall long-term benefit. It is significant that simply by changing the required method of financial reporting, nearly one-half of the respondents would spend less of their total R\&D budget on short-term projects and more on longterm. It is apparent that required financial reporting is influencing corporate financial management to make decisions that conflict with sound R\&D management and the long-term benefit of the company.

A pressing problem in $R \& D$ budgeting in many companies is annual fluctuation of $R \& D$ expenditures. This is certainly due, in part, to keeping short-term financial reported profits stable or positive. With this is mind, respondents were asked the following question: "After enactment of this proposal, what effect (if any) relative to present practice will there be in the annual fluctuations (if any) of $R \& D$ expenditures?" Over one-third (33\%) of the respondents replied that there would be a decrease in annual fluctuations, $8 \%$ indicated an increase, while the remaining $56 \%$ believed there would be no effect. We are not suggesting there would not be annual fluctuations in R\&D expenditures but rather that fluctuations should not be a result of financial reporting requirements which may pressure managers to decrease $R \& D$ at times when it is most badly needed.

Finally, answering the last questions, "Do you feel this contra stockholders' equity method of accounting for R\&D may allow U.S. companies to compete more effectively in the international market?" $42 \%$ of the respondents answered yes, $54 \%$ no and $4 \%$ not sure. Presumably, the respondents answering "yes" did so because they felt that the proposed method would provide an incentive for more to be spent on R\&D or a shift in R\&D to longer term projects or both.

A separate part of the questionnaire listed four proposed methods of reporting research and development expenditures in published financial statements. After reading the four methods, respondents were asked to indicate on a scale, from 1-least appropriate, to 7-most appropriate how appropriate each method would be for their firm. The methods scored, respectively, as follows: the expense-as-incurred method in practice, an average of 5.6; the proposed contra stockholders' equity method, and average of 4; a capitalization and fixed write-off method, and average of 2.5; and a choice of either capitalization (shown as an asset) or charge to income as incurred, depending on estimates of future productiveness, an average of 2.6. It is noteworthy that the proposed contra stockholder method scored almost as high as the expense-as-incurred method use in practice. This is particularly so because the above numbers represent the averages for all respondents. Figure 1. shows relative appropriateness of each of four possible methods of accounting for research and development costs as published financial statements. 
Figure 1

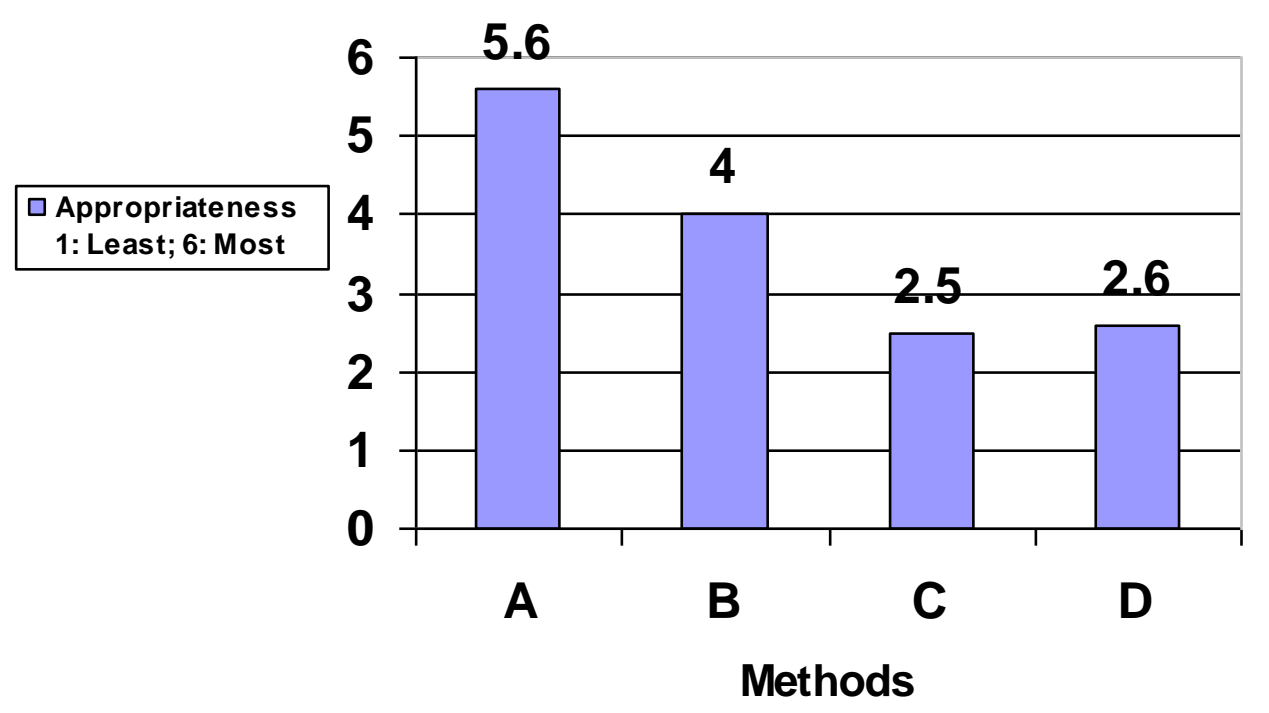

A: Expense as Incurred
B: Contra Stockholders' Equity
C: Capitalization and Fixed Write-off
D: Choice of Either Expense or Capitalization

\section{Conclusions}

Results from this study tentatively indicate that if the contra stockholders' equity method were used for the financial reporting of $R \& D$ expenditures, a larger total dollar amount of $R \& D$ would be spent, a shift in total R\&D toward longer projects would occur, U.S. companies would compete more effectively in the international market, and the relevancy of financial accounting earnings would be improved. Thus, the expense-as-incurred method of accounting for R\&D is impeding sound corporate R\&D decision making. However, the respondents still selected that the most appropriate method of accounting for R\&D is the expense-as-incurred method. They indicated, in writing, a concern that a less favorable R\&D tax policy could be the result of any change, but tax policy need not be changed.

\section{Suggestions for Future Research}

Since R\&D Expenditures are such an important component in business enterprise continued research into possible capitalization and future write-off of $R \& D$ should occur. This additional research should be undertaken regarding the financial reporting of R \& D expenditures, R \& D tax policy, and the impact of the proposed contrastockholders' equity method on company size within all industries.

\section{References}

1. Abrahams, T. and B. Sidho, The Role of R\&D Capitalizations in Firm Valuation and Performance Measurement, Austrian Journal of Management, pp. 169-183, 1998.

2. Ball, R. Discussion of Accounting for Research and Development Costs: The Impact on Research and Development Expenditures, Journal of Accounting Research, pp. 27-37, 1980.

3. Barth, M. and G. Clinch, Revalued Financial, Tangible and Intangible Assets, Journal of Accounting Research, pp. 199-233, 1998. 
4. Bierman, H. and R. E. Dukes, Accounting for Research and Development Costs, The Journal of Accountancy, pp. 48-55, April, 1975.

5. Biggadike, R., The Risky Business of Diversification, Harvard Business Review, pp. 103-111, May-June, 1979.

6. Braithwaite, M. E., Management Control of Research Expenditure and Its Interest to the Auditor, Accountancy, pp. 248-249, April, 1967.

7. Carnegie, G. and S. Turner, Accounting for Research and Development Costs - A Company Response to AAS No. 13, The Chartered Accountant in Australia, March 1987.

8. Compustat Data Bank, 1999.

9. Council on Competitiveness, The New Challenge to America's Prosperity: Findings from the Innovation Index, Vol. 42, No. 3, pp. 3-4, May, 1999.

10. Dukes, R. E., T. R. Dyckman, and J. A. Elliott, Accounting for Research and Development Costs: The Impact on Research and Development Expenditures, Journal of Accounting Research, pp. 1-25, 1980.

11. Elliot, J. and others, eds., The Impact of SFAS No. 2 on Firm Expenditures on Research and Development: Replications and Extensions, Journal of Accounting Research, pp. 85-101, Spring, 1984.

12. Financial Accounting Standards Board, Accounting for Research and Development Costs, Financial Accounting Standards Board Statement Number 2, para. 1-76, 1974.

13. Financial Accounting Standards Board, Accounting for the Costs of Computer Software to be Sold, Leased, or Otherwise Marketed, Financial Accounting Standards Board Statement Number 86, 1985.

14. Gellein, Oscar S. and Maurice S. Newman, Accounting for Research and Development Expenditures, Accounting Research Study No. 14, American Institute of Certified Public Accountants (New York 1973).

15. Guerard, J., et al., R and D Management and Corporate Financial Policy, Management Science pp. 1419-1427, November, 1987.

16. Higgins, T., Deferral vs. Charge-off of Research and Development Costs, Annual Meeting Papers, American Institute of Certified Public Accountants, New York, 1954.

17. Horwitz, B. and R. Kolodny, The Economic Effects of Involuntary Uniformity in the Financial Reporting of R\&D Expenditures, Journal of Accounting Research, pp. 38-73, 1980.

18. Lev, B., The Relevance of Financial Accounting, Journal of Accounting Research, pp. 353-385, Autumn, 1999.

19. Marshall, W., Discussion of the Economic Effects of Involuntary Uniformity in the Financial Reporting of R\&D Expenditures and Accounting for Research and Development Costs: The Impact on Research and Development Expenditures, Journal of Accounting Research, pp. 84-107, 1980.

20. Munson, R., An Asset That Shouldn't Be Written Off, Accountancy, pp. 26, December, 1987.

21. Newman, M., Accounting for Research and Development, Research Technology Management, pp. 6-7, JulyAugust, 1988 .

22. Nix, P. E. and D. E. Nix, An Historical Review of the Financial Accounting of Research and Development Costs, The Accounting Historians Journal, Vol 19, NO. IV, June 1, 1992.

23. Nixon, B. and A. Lonie, Accounting for R\&D: The Need for change, Accountancy, pp. 90-91, February, 1990.

24. Raby, W. L., The Impact of Income Taxes on Corporate Research, The Journal of Accountancy, pp. 53-56, August, 1967.

25. Selto, F. H. and M. L. Clouse, An Investigation of Managers' Adaptations to SFAS No. 2: Accounting for Research and Development Costs, Journal of Accounting Research, pp. 700-717, Autumn, 1986.

26. Tax Foundation, Tax Features, p. 6, March, 1990.

27. Thomas, A. L., The Allocation Problem in Financial Accounting Theory, (George Banta Company, Inc., Evanston, IL, 1969).

28. Wolff, M. F. (ed.), Meet Your Competition: Data from the IRI R\&D Survey, Research Technology and Management, pp. 18-23, January-February, 1994.

29. Wolff, M. F. (ed.), Perspectives, Research Technology and Management, p. 3, May-June, 1989.

30. Wolff, M. F. (ed.), U.S. R\&D Spending Outlook Continues Strong for 2001, Research Technology Management, pp. 5-7, Sept-Oct, 2000.

31. Wolfson, M. A., Discussion of the Economic Effects of Involuntary Uniformity in the Financial Reporting of R\&D Expenditures, Journal of Accounting Research, pp. 75-83, 1980. 